\title{
TECHNICAL EFFICIENCY OF POULTRY EGG PRODUCTION IN OGUN STATE, NIGERIA
}

\author{
Olatokunbo H. Osinowo ${ }^{1 凶}$, Esther T. Tolorunju $^{2}$ \\ ${ }^{1}$ Ogun State Ministry of Agriculture, Abeokuta, Nigeria \\ ${ }^{2}$ Federal University of Agriculture Abeokuta, Ogun State, Nigeria
}

\begin{abstract}
There is a retarded growth in poultry egg production in Ogun state, Nigeria. This has led to high production costs and average market prices of the product. Therefore, this study examined the technical efficiency of poultry egg production in Ogun state, Nigeria using the stochastic frontier production function model. Primary data was collected using a set of structured questionnaires from one hundred and twenty (120) poultry egg farmers (selected using multi-stage sampling techniques) from the Poultry Association of Nigeria, Ogun State Chapter. The level of technical efficiencies (TE) varied widely across farms, ranging between $64 \%$ and $97 \%$, with a mean value of $85.6 \%$. Only "years of experience" negatively affected the TE while an increase in other socio-economic variables, such as education, age and farm location, led to an increase in the TE value. The major constraints in poultry egg production included unbearable costs of feed, inadequate funds and capital, lack of disease control facilities and unstable power supply. This study recommends the dissemination of improved modern technology in egg production to poultry egg farmers.
\end{abstract}

Keywords: egg production, stochastic frontier analysis, technical efficiency

\section{INTRODUCTION}

Egg production is a vibrant sub-sector of the livestock industry in Ogun State, Nigeria. Substantial numbers of small, medium and large-scale poultry farms are key players in this industry. According to Apantaku et al.
(1998), the development of the poultry industry has also been described as the fastest means of bridging the protein deficiency gap prevailing in the country. He also concluded that most African diets (including Nigerian) are deficient in animal protein which result in poor and stunted growth, and in accelerated spread of diseases and, consequently, deaths. Osinowo (1998) and Otunaiya et al. (2015) observed that apart from the provision of direct employment and a livelihood to thousands of people, the poultry egg industry provides remarkably high-quality nutritious food (especially animal protein) in a discrete, convenient and handy packet.

One of the development challenges facing most developing countries is their inability to adequately feed their ever-increasing population with the right proportion of calories and protein (Adedeji et al., 2013). The nutritional status of many Nigerians is therefore characterized by a low calorie and protein intake. Most animal proteins are delicious but not easily affordable. Other animal protein sources include fish, poultry meat, beef, milk, bacon, pork and mutton, but poultry eggs are the most easily affordable to common people (Apantaku, 2006).

The level of poultry productivity is not yet commensurate with the level of technologies being developed by Nigerian poultry production researchers (Akintunde et al., 2015; Aladejebi et al., 2014; Apantaku et al., 1998; Eekeren et al., 1995). The problems associated with poultry production in South West Nigeria are low egg production per hen, diseases and pest, low and poor

$\bowtie$ Olatokunbo H. Osinowo, PhD, Ogun State Ministry of Agriculture, Dept of Planning, Research and Statistics, Oke-Mosan, Abeokuta, Ogun State, Nigeria, e-mail: writetokzy@yahoo.com, https://orcid.org/0000-0003-0263-0287 
performing breed, poor weight gain / feed conversion, feeding and management problems and lack of capital (Aladejebi et al., 2014; Akintunde et al., 2015).

In 2015 , the industry had over 1280 registered commercial poultry farms in the state with estimated $5,917,118$ birds in production. That year, the industry earned a reputation as the poultry basket of Nigeria (Poultry Association of Nigeria, Ogun State Chapter) (PANOG, 2015). Small producers made up $68.6 \%$ of the total producer population, while medium and large producers constituted $17.3 \%$ and $14.1 \%$, respectively. This shows that egg production was in the small scale category in the study area. This is consistent with the following classification by Omotosho and Ladele (1988) and Ojo (2003): small poultry farms (up to 1000 birds), medium farms (between 1001 and 4999 birds) and large farms (above 5000 birds).

Recent observations (Afolami et al., 2013; Otunaiya et al., 2015) show that the protein consumption pattern in Nigeria continues to be below the Food and Agriculture Organization (FAO) recommended level of 35 gram per capita per day. According to Ojo (2003), the average level of animal protein consumption was 5 gram per capita per day which is far cry from the level recommended by FAO. One of the reasons proffered by most researchers is the low productivity level of resources employed, arising from the inefficient allocation of resources in poultry industry.

According to Otunaiya et al. (2015), despite the growth in egg production industry in Nigeria since 2000, local demand has not been matched by local supply. In 2011, the Nigerian egg production stood at 636.000 million metric tons. With a population of about 165 million in 2011, a huge demand/supply gap was created, thus hindering the "one egg per day" advocacy process. Optimum production efficiency can be achieved by an effective use of available inputs which improves the output level.

Due to some problems, the poultry egg production industry fails to effectively supplement the animal protein content in the average consumer's diet in Ogun State. These problems center on a low growth rate of poultry birds, resulting in high production costs. The general abundance of eggs does not mean the supply actually exceeds the demand. Instead, the high unit cost makes eggs unaffordable to wide swaths of the population.

The need for a cheap source of protein in the food basket of an average local consumer cannot thus be ignored. This is especially true considering the low economic status of an average resident of the state and the ever-growing population.

Due to low productivity, the unit production cost of eggs has been on the increase, resulting in the escalating price of the product. For instance, a crate of eggs was sold for NGN 300 in 2000 and NGN 350 in 2003 (CBN, 2003). Presently, the average price is NGN 800 per crate.

Although some studies on the poultry industry have been carried out (Afolami et al., 2013; Akintunde et al., 2015; Aladejebi et al., 2014; Chukwuji et al., 2006; Ojo 2003; Ojo and Afolabi, 2000; Otunaiya et al., 2015), the technical efficiency of poultry egg production in Ogun State, Nigeria was specifically documented only in few of the related research papers. The distinctive feature of this study is the methodology adopted and the study area, considering that the Ogun State poultry industry has earned the reputation of the Nigerian poultry basket over the last year. Therefore, the identification of the sources of inefficiency is crucial to the implementation of public and private policies designed to improve performance. This process would provide a basis for formulating a policy on the factors to be targeted in an effort to raise the current efficiency level of poultry farmers.

An understanding of these relationships is expected to provide the working tools for policymakers. This would empower them to design a program that can contribute to measures needed to expand poultry egg production in Ogun State in particular and in the country in general. The specific objectives of this study are to:

- Describe the socio-economic characteristics of poultry farmers

- Identify production constraints militating against increased level of egg production

- Estimate the level of technical efficiency of poultry egg farmers in Ogun State.

\section{STOCHASTIC FRONTIER PRODUCTION FUNCTION AND TECHNICAL EFFICIENCY ESTIMATION}

Technical efficiency refers to the achievement of maximum potential output from a given quantity of input, taking into account the physical production relationship (Bamiro et al., 2006). A farm is said to be technically inefficient if too little output is being produced from a given bundle of inputs. Hence, enterprise inefficiency involves disproportionate and excessive usage of all inputs. 
The use of the stochastic frontier production function in economic analyses has gained in prominence in econometrics and applied economic analysis over the last two decades. Early applications of the stochastic frontier production function in economic analyses include research by Aigner et al. (1977) who used it to analyze U.S. agricultural data. Empirical applications of this technique in efficiency analysis have been reported by Battese et al. (1993). The stochastic frontier production function model is specified as follows:

$$
\ln Y_{i}=\ln \beta_{0}+\Sigma \beta_{j} \ln x_{i j}+v_{i}-u_{i}
$$

where:

$Y$ - is the output in a specified unit,

$X_{j}$ - denotes the actual input vector;

$\beta_{j}-$ is the vector of production function parameters.

The frontier production function $F\left(X_{j} \beta_{j}\right)$ is a measure of maximum potential output for any particular input vector $X_{j}$. The $V_{i}$ and $U_{i}$ cause actual production to deviate from the frontier. The $V_{i}$ captures the random variation in output which is due to factors beyond the control of the producer (e.g. temperature, moisture, natural hazards). The $V_{i}$ is assumed to be independently identically distributed with zero mean and constant variance $\left(0, \sigma_{v}^{2}\right)$, and to be independent of $U_{i}$.

The $U_{i}$ is a non-negative term representing the deviations from the frontier production, which is attributed to controllable factors (technical inefficiency). It is half normal, identically and independently distributed with zero mean and constant variance: $\mathrm{N}\left(0, \sigma_{u}^{2}\right)$. The stochastic frontier production function model is established using the maximum likelihood estimation procedure (MLE), a maximum techniques (Olowofeso and Ajibefun, 1999).

The technical efficiency is empirically measured by decomposing the deviation into a random component (U). According to Ojo (2003), the technical efficiency of an individual farm is defined as the ratio of observed output $\left(Y_{i}\right)$ to the corresponding frontier output $\left(Y_{i}^{*}\right)$ for the available technology, that is:

$$
\begin{gathered}
T E=\frac{Y_{i}}{Y_{i}^{*}} \\
\frac{\ln \beta_{0}+\Sigma \beta_{j} \ln x_{i j}+v_{i}-u_{i}}{\ln \beta_{0}+\Sigma \beta_{j} \ln x_{i j}+v_{i}}
\end{gathered}
$$

so that $0 \leq \mathrm{TE} \leq 1$.

\section{MATERIALS AND METHOD}

This study used primary and secondary data. Primary data was collected through a structured questionnaire designed to collect information on output, input, prices of outputs and inputs, and some major socio-economic characteristics of the farmers in the study area. In turn, secondary data was obtained from various publications relevant to poultry production. According to PANOG classification, there are 6 zones in Ogun State. To ensure an even distribution of the sample for this study, a multistage sampling technique was employed in the selection of the respondent poultry farms. The first stage involved the selection of six (6) PANOG zones where the poultry farms are located, i.e. Egba, Ijebu, Ota, Remo, Mowe and Yewa. However, the second stage involved the selection of poultry farms based on their scale of operations i.e. small, medium and large farms. The final step was the simple random selection of poultry farmers in each zone by scale of operation. Explicitly, 50\% (i.e. 60 poultry farmers) were randomly selected from the small-scale operator group and $25 \%$ (i.e. 30 poultry farmers) were selected from each of the medium and large-scale poultry units, thus giving a total of 120 respondents for the study.

Descriptive statistics (mean, frequency and percentages) were used to achieve objectives one and two. The stochastic production frontier model was used to analyze objective three.

\section{Model specification}

The stochastic frontier production function was used to analyze the technical efficiency. The production technology employed by the farmers will be assumed to be specified by the Cobb-Douglas frontier production function (Tadesse and Krishnamoorthy, 1997), defined as:

$$
l_{n} Y_{i}=l_{n} \beta_{0}+\beta_{1} l_{n} X_{1 i}+\beta_{2} l_{n} X_{2 i}+\beta_{3} l_{n} X_{3 i}+\beta_{4} l_{n} X_{4 i}+V_{i}-U_{i}
$$

where:

$Y$-value of eggs produced annually (NGN),

$X_{1}$-stock of birds (number),

$X_{2}$-feed intake $(\mathrm{kg})$,

$X_{3}$-operating expenses (cost of labor, drugs and transportation) in NGN,

$X_{4}$-other cost (depreciation costs) in NGN,

$V_{i}$-random errors,

$U_{i}$-technical inefficiency as defined below, 


$$
U_{i}=\delta_{0}+\delta_{1} Z_{1 i}+\delta_{2} Z_{2 i}+\delta_{3} Z_{3 i}+\delta_{4} Z_{4 i}
$$

where:

$$
\begin{aligned}
& Z_{1} \text {-years of experience } \\
& Z_{2} \text { - years of schooling } \\
& Z_{3} \text { - age of farmers } \\
& Z_{4} \text { - farm location }
\end{aligned}
$$

These are included in the model to indicate their possible impact on the technical efficiencies of poultry farmers.

$\beta$ s and $\delta$ s are scalar parameter to be estimated. The variances of random errors $\left(\sigma v^{2}\right)$, the variance of the technical inefficiency effect $\left(\sigma u^{2}\right)$ and the overall variance of the model $\left(\sigma^{2}\right)$ are related as follows:

$\sigma^{2}=\sigma v^{2}+\sigma u^{2}$. The ratio $\sigma^{2}=\sigma u^{2} / \sigma v^{2}$ measures the total variation of output from the frontier which can be attributed to technical inefficiency (Battese and Cora, 1977). The estimates for all the parameters of the stochastic frontier production and the inefficiency model are simultaneously obtained using the frontier program, version 4.1 (Coelli, 1994).

\section{RESULTS AND DISCUSSION}

\section{Socio-economic characteristics}

of poultry egg farmers

Based on a descriptive examination of socio-economic characteristics of poultry egg farmers in Table 1 , the study revealed that $41 \%$ of respondents fall within the age group of 41-50 years with a mean of 44.8. This indicates that most respondents were in their prime age of labor productivity. Most of them (88.34\%) were male. The study also shows that many poultry farmers were educated, with ca. 14.3 years of schooling. About $68.3 \%$ of farms were located in urban centers. As shown by the results, $85 \%$ of farmers were married and had a mean household size of 6 persons. The mean farm experience is 10 years with a range of 2 to 36 years; $67.5 \%$ of farmers operate on part time.

\section{Production constraints faced by the respondents}

Table 2 revealed that "unbearable cost of feeding" $(81.66 \%)$ was one of the major problems confronting the egg producers in the study area, since feed costs are the major expenses in poultry breeding and thus hinder egg production. Inadequate funds and capital $(72.50 \%)$ was also a major problem, which suggested why the
Table 1. Socio-economic characteristics of poultry egg farmers

\begin{tabular}{lcc}
\hline \multicolumn{1}{c}{ Characteristics } & Frequency & Percentage (\%) \\
\hline Age (years) & & \\
\hline$\leq 30$ & 10 & 8.33 \\
$31 \leq 40$ & 34 & 28.34 \\
$41 \leq 50$ & 49 & 40.84 \\
$51 \leq 60$ & 17 & 14.16 \\
$61 \leq 70$ & 9 & 7.50 \\
$>70$ & 1 & 0.83
\end{tabular}

Gender

Male

Female

Education level

No formal education

1.66

Primary education

5.00

Secondary education

17.50

Tertiary education

75.84

Farm location

Rural

31.66

Urban

68.34

Marital status

Single

10.84

Married

85.00

Divorced

4.16

Household size

1-3

13.34

4-6

60.84

7-9

19.16

10 or above

6.66

Years of experience

$<10$

62.50

11-20

30.00

21-30

6.67

$>30$

0.83

Occupational group

Full-time poultry farmers

Part-time poultry farmers

Total

100.0 
Table 2. Distribution of respondents by production constraints

\begin{tabular}{lcc}
\hline \multicolumn{1}{c}{ Constraints } & Frequency** & Percentage (\%) \\
Inadequate funds and capital & 87 & 72.50 \\
Excess market supply & 19 & 15.83 \\
Pilferage and theft & 20 & 16.66 \\
Diseases & 49 & 40.83 \\
High mortality rate & 26 & 21.66 \\
High rate of cracked eggs & 8 & 6.66 \\
Low egg production & 33 & 27.50 \\
Unbearable cost of feeding & 98 & 81.66 \\
Unstable power supply & 52 & 43.33 \\
Other & 24 & 20.00 \\
\hline
\end{tabular}

**Multiple responses.

poultry industry was not operating at full capacity in the study area. The probable reason for this may be the fact that only few respondents had access to credit facilities or loans from financial institutions. This is consistent with earlier reports (Agbato, 1997; Akeeb, 1997) which confirmed that credit facilities or loans from financial institutions are not accessible to rural poultry farmers. Also, $43.33 \%$ of the respondents claim that unstable power supply is one of the militating factors against egg production in the study area, since they incurred an extra cost to run a power generator for compounding feed and pumping water from the borehole.

\section{Estimates of the stochastic frontier production function parameter}

The production function and inefficiency model parameters were estimated using the Maximum Likelihood Estimation method. The results are presented in Table 3. The generalized Likelihood Ratio Test revealed the presence of technical inefficiency effects. The coefficients for the stock of birds and other costs (Depreciation cost) are statistically significant at $1 \%$ and $5 \%$ respectively. The coefficients for all other variables were not significant. The coefficient for the stock of birds is 0.9269 , which implies that a unit increase in the stock of birds leads to a 0.93 unit increase in the egg production level. Similarly, a unit increase in other costs entails a 0.05 unit decrease in the farmers' output per bird.
Table 3. Maximum likelihood estimate of the stochastic frontier production function

\begin{tabular}{lcc}
\hline \multicolumn{1}{c}{ Variable } & Parameter & $\begin{array}{c}\text { Max. Likelihood } \\
\text { Estimate }\end{array}$ \\
\hline Constant & $\beta_{0}$ & $\begin{array}{c}5.7715^{*} \\
(26.62)\end{array}$ \\
Stock of birds $\left(X_{1}\right)$ & $\beta_{1}$ & $0.9269^{*}$ \\
& & $(5.29)$ \\
Feed consumed $\left(X_{2}\right)$ & $\beta_{2}$ & 0.0895 \\
Operating expenses $\left(X_{3}\right)$ & $\beta_{3}$ & $(0.48)$ \\
& & 0.0361 \\
Other costs $\left(X_{4}\right)$ & $\beta_{4}$ & $-0.047)$ \\
& & $(-1.64)$
\end{tabular}

Inefficiency model

$\begin{array}{lcc}\text { Constant } & \delta_{0} & 0.3260 \\ \text { Experience } & & (1.37) \\ & \delta_{1} & 0.0018 \\ \text { Years of schooling } & \delta_{2} & -0.0034 \\ & & (-0.33) \\ \text { Age of farmers } & \delta_{3} & -0.0041 \\ & & (-0.81) \\ \text { Farm location } & \delta_{4} & -0.0648^{* *} \\ & & (-1.89) \\ \text { Sigma squared } & \sigma_{2} & 0.0338 \\ \left(\sigma 2=\sigma u_{2}+\sigma v_{2}\right) & & (1.66) \\ \text { Gamma } & \gamma & 0.8061 \\ & & (5.92) \\ \text { Log likelihood function } & & 63.05 \\ \text { LR TEST } & & 5.7389\end{array}$

$*$ and $* *$ denote statistical significance at $1 \%$ and $5 \%$, respectively. Figures in parentheses are $t$-values.

The variance ratio defined as $\sigma^{2}=\sigma u^{2} / \sigma v^{2}$ was estimated to be $0.8061(81 \%)$, suggesting that systematic impacts that are not explained by the production function are the dominant sources of random errors. Thus, the estimated model has been derived as:

$$
\begin{gathered}
l_{n} Y_{i}=5.7715+0.9269 X_{1}+0.0895 X_{2}+ \\
0.0361 X_{3}-0.0451 X_{4}
\end{gathered}
$$

From the model equation, it follows that a unit increase in the stock of birds, feed consumed and operating 
expenses will result in a $0.93,0.09$, and 0.04 unit increase (respectively) in the output, while a unit increase in other costs will decrease the output by 0.05 units.

Factor productivity could be improved by adjusting the level of other costs (fixed input) or expanding the farm size at existing level of operation, so that the variable of other costs could move from stage III to stage II of the production space. Since the stock of birds has the highest coefficient, it means that an increase in the stock of birds has a stronger positive impact on the output of poultry farms than an increase in other factors that influence poultry output, as specified in this study.

\section{Technical efficiency analysis}

The predicted farm technical efficiency (TE) varied in the range of $64 \%$ to $97 \%$, with a mean of $85.6 \%$, indicating high efficiencies in poultry production. Thus, in the short run, there is room for increasing egg production by ca. $14.4 \%$ with the available farm resources and technology. This can be done by adopting the technology and techniques used by best-practice poultry farms. One of such measures focuses on the negative coefficient of fixed costs. The level of efficiency is as shown in Table 4. Accordingly, ca. $39.17 \%$ of the sampled poultry farms had technical efficiencies exceeding $90 \%$, operating close to the frontier. About $53.33 \%$ of farmers had technical efficiencies varying in the range of $70 \%$ to $89 \%$ while ca. $7.50 \%$ of poultry farms had a technical efficiency below $70 \%$.

Table 4. Technical efficiency analysis

\begin{tabular}{lcc}
\hline Decile range of TE & Frequency & Percentage \\
\hline $0.60-0.69$ & 9 & 7.50 \\
$0.70-0.79$ & 23 & 19.16 \\
$0.80-0.89$ & 41 & 34.17 \\
$0.90-0.99$ & 47 & 39.17 \\
Total & 120 & 100 \\
\hline
\end{tabular}

mean $=85.6 \%$, $\min .=64 \%, \max .=97 \%$

\section{Technical inefficiency analysis}

As revealed by the analysis of the inefficiency model (Table 3), the signs and significance of the estimated coefficients in the inefficiency model have important implications for the farmers' technical efficiency. The coefficient of years of experience $\left(\delta_{1}\right)$ was positive, indicating that this factor led to an increase in technical inefficiency (or to a decrease in technical efficiency of poultry egg production). The a priori expectation is that technical efficiency should increase with an increase in years of experience, since experience is expected to be positively correlated with the adoption of improved production technology and techniques (Ojo and Afolabi, 2000). This may be due to the fact that the more experienced the farmers, the less time they had for efficient supervision of their poultry farms because of their involvement in other farming activities, such as piggery farming, fish farming or arable farming as a way of diversification. Most experienced farmers tend to get involved in other farming activities as their years of experience increase. As a consequence, they have less time for an efficient supervision of the poultry section.

However, the coefficients for years of schooling $\left(\delta_{2}\right)$, age of farmers $\left(\delta_{3}\right)$ and farm location $\left(\delta_{4}\right)$ were negative, implying that these factors led to a decrease in the technical inefficiency or an increase in technical efficiency of poultry egg production in the study area. The coefficients of farm location are statistically significant at $5 \%$; all of these factors met the a priori expectation. The negative impact of years of schooling indicates that the technical efficiency rises with an increase in years of schooling since education is an important factor in recognizing and seizing investment opportunities. Highly educated farmers are more likely to adopt innovations than the illiterate ones (Agbamu, 1993). Moreover, the farmers' age contributed negatively to inefficiency. This indicates that the older the farmer, the smaller the technical inefficiency or the greater the technical efficiency. On the contrary, an earlier report by Ojo (2003) shows that the older the farmer, the less technically efficient the farm. This may be due to the fact that older farmers are more exposed and less risk averse.

The negative effect of the location of poultry farms implies that technical efficiency increases as the farm is located near urban centers where the population is large and effective demand for eggs is assured. The TE for rural areas decreases due to sparse population and relatively low demand for eggs as a result of low rural incomes. Thus, the study observed that the nearer the poultry farm to an urban center, the higher the technical efficiency. This is consonance with the finding of Ojo (2003) that the technical efficiency increases in urban areas. 


\section{CONCLUSION AND RECOMMENDATIONS}

The study showed that poultry production is generally profitable but the degree of profitability is determined by the poultry farm size. The stock of birds, feed consumed and operating expenses have a positive significant effect on the output of poultry farms. This indicates that the output of poultry farms increased with a rise in the stock of birds, feed consumed and operating expenses. The results of the inefficiency model reveal that years of schooling, age of farmers and farm location are variables with a negative coefficient, implying that the farms tend to be less inefficient in egg production. To achieve a higher level of poultry egg production, there is the need to increase the technical efficiency of poultry farms in Ogun state through adoption of appropriate technology and by intensifying the efforts of extension agents in providing the farmers with training on new management practices involved in poultry egg production.

The policy implication of the above findings is that there are ample opportunities to raise the present level of technical efficiency of poultry egg production in the study area, given the wide variation in the level of technical efficiency. Since the education variable has a relationship with the level of technical efficiency, the government should organize formal education programs through extension services for the farmers. More agricultural extension efforts should be devoted to the dissemination of improved modern technology in egg production to the farmers. This will go a long way in improving their technical knowledge and hence their technical efficiency.

The unbearable cost of feeding is the major threat facing poultry farmers. Feed costs account for about $81 \%$ of the total production cost. It is recommended that efforts be made to improve local/domestic production (instead of importation) of poultry feed raw materials such as maize and wheat through the provision of incentives and input subsidies to farmers in order to provide feed for the poultry industry. This will reduce the production costs, leading to increased revenues.

In view of the huge financial outlay required to establish and maintain the poultry farms, credit institutions should continue to support the poultry sector with low interest rates in the interest of all and sundry. This study also recommends the provision of affordable health services for timely vaccination of poultry birds to prevent and control disease problems.

\section{REFERENCES}

Adedeji, I. A., Adelalu, K. O., Ogunjimi, S. I., Otekunrin, A. O. (2013). Application of Stochastic Production Frontier in the Estimation of Technical Efficiency of Poultry Egg Production in Ogbomoso Metropolis of Oyo State, Nigeria. World J. Agric. Res., 1(6), 119-123.

Afolami, C. A., Aladejebi, O. J., Okojie, L. O. (2013). Analysis of Profitability and Constraints in Poultry Egg Farming Under Battery Cage and Deep Litter Systems in Ogun State. Nigeria: A Comparative Study. IJAFS, 4(20), 581-595.

Agbamu, J. U. (1993). Analysis of Farmers' characteristics associated with adoption of soil Management Innovation in Ikorodu L.G.A of Lagos State. Nig. J. Rural Ext. Dev., $1(2-3), 57-67$.

Agbato, O. A. (1997). Effective strategies for egg marketing in Nigeria. Paper presented at a workshop organized by the Nigeria Society for Animal Production(NSAP). Ogun State, Nigeria.

Aigner, D. J, Lovell, C. A. K., Schmidt, P. (1977). Formulation and Estimation of Stochastic Frontier Production Models. J. Econ., 6, 21-37.

Akeeb, S. (1997). Problems of poultry production in Nigeria. Paper presented at Workshop, organized by the Nigeria Society for Animal Production (NSAP). Ogun State, Nigeria.

Akintunde, O. K., Adeoti, A. I., Okoruwa, V. O., Omonona, B. T., Abu, A. O. (2015). Effect of Disease Management on Profitability of Chicken Egg Production in Southwest Nigeria. Asian J. Poul. Sci., 9, 1-18.

Aladejebi, O. J., Okojie, L. O., Afolami, C. A. (2014). Comparative Production Efficiency of Battery Cage and Deep Litter System in the Drive Towards Sustainable Poultry Egg Farming in Ogun State, Nigeria. J. Sust. Dev. Afr., 16(4), 139-159.

Apantaku, S. O., Omotayo, A. M., Oyesola, A. B. (1998). Poultry farmers willingness to participate in Nigeria Agriculture Insurance Scheme in Ogun state, Nigeria. In: O. O. Oduguwa, A. O. Fanimo, O. A. Osinowo (Eds.), Proceeding of the silver anniversary conference, Nigerian Society for Animal Production. Gateway Hotel, Abeokuta, 21-26 March 1998, 542.

Apantaku, S. O. (2006). Analysis of participation of farmers in participatory poultry production research in Lagos State, Nigeria. Livest. Res. Rural Dev., 18(7).

Bamiro, O. M., Phillip, O. A., Momoh, S. (2006). Vertical Integration and Technical Efficiency in Poultry (Egg) Industry in Ogun and Oyo States, Nigeria. Int. J. Poul. Sci., 5(12), 1164-1171. 
Battese, G. E., Malik, S. J., Broca, S. (1993). Production Function for wheat farmers in selected district of Pakistan. An application of stochastic frontier production function with time varying inefficiency effect. The Pak. Dev. Rev., 32, 233-268.

Battese, G. E., Corra, G. S. (1977). Estimation of a Production Frontier Model with Application to the Pastoral Zone of Eastern Australia. Aust. J. Agric. Eco., 21, 169-179.

Central Bank of Nigeria, CBN (2003). Annual Report and Statement of Account. CBN Publications.

Chukwuji, C. O., Inoni, O. E, Ogisi, O. D., Oyaide, W. J. (2006). A Quantitative Determination of Allocative Efficiency in Broiler Production in Delta State. Agriculture Conspectus Scientificus, 71(1), 21-26.

Coelli, T. J. (1994). A Guide to Frontier Version 4.1: A computer program for stochastic, frontier production and cost function estimation. Armidale: Mimeo, Department of Econometrics, University of New England.

Eekeren, N. V., Mass, A., Saatkamp, H. W., Verschuur, M. (1995). Small Scale Poultry Production in the Tropics $\left(2^{\text {nd }}\right.$ rev. ed.). Wageningen: Agromisa Foundation.

Food and Agriculture Organisation (1992, 2004). FAOSTAT. Database. Retrieved from: www.fao.org

Ojo, S. O. (2003). Productivity and technical efficiency of Poultry egg Production in Nigeria. International Journal of Poultry egg Production in Nigeria. Int. J. Poul. Sci., 2(6), 459-464.

Ojo, S. O., Afolabi, J. A. (2000). Economic Analysis of Replacing the Fish Meal Component in Broiler Starter Mash with Glyricidia sepium. Production in the new millennium, Challenges and Option. Book for proceeding. Farm. Jan.

Olowofeso, O. E., Ajibefun, I. A. (1999). The Maximum Likelihood Estimation of Stochastic Frontier Production Function with Technical Efficiency Using Time Series Data. J. Sci. Eng. Tec., 6, 1527-1536.

Omotosho, O. A., Ladele, A. A. (1998). Management problem in large scale poultry business in Nigeria. Farm Manag. Assoc. Nigeria (FAMAN) J., 3, 27-35.

Osinowo, O. A. (1998). To Sell an Egg. Egg update (10 $0^{\text {th }}$ ed.). A publication of CEPAN.

Otunaiya, A. O., Adeyonu, A. G., Bamiro, O. M. (2015). Technical Efficiency of Poultry Egg Production in Ibadan Metropolis, Oyo State, Nigeria. Nig. J. Econ., 4(3), 50-56.

PANOG (2015). Poultry Association of Nigeria, Ogun State Chapter. Annual Reports. PANOG Publications.

Tadesse, B., Krishnamoorthy, S. (1997). Technical efficiency in paddy farms of Tamil Nadu: An analysis based on farm size and ecological zone. J. Agric. Eco., 16, 185-192. 